Gilang Nursandhi,A.Marzuki dan Suratno, Substitusi Pakan Komersial Oleh Tepung Daun Semak Bunga Putih (Chromolaena odorata) Terfermentasi Terhadap Performa Dan IOFC (Income Over Feed Cost) Ouyuh Pedaging

\title{
SUBSTITUSI PAKAN KOMERSIAL OLEH TEPUNG DAUN SEMAK BUNGA PUTIH (Chromolaena odorata) TERFERMENTASI TERHADAP PERFORMA DAN IOFC (Income Over Feed Cost) PUYUH PEDAGING
}

\author{
Oleh : \\ Gilang Nursandhi*), Achmad Marzuki**) dan Suratno***)
}

\begin{abstract}
ABSTRAK
Penelitian ini bertujuan mengetahui sejauh mana proses fermentasi dapat memperbaiki kualitas kandungan nutrisi tepung daun Semak Bunga Putih (Chromolaena odorata), serta pengaruh penggunaannya dalam ransum terhadap performa dan IOFC puyuh pedaging. Penelitian ini menggunakan metode eksperimental dengan memakai rancangan acak lengkap (RAL) pola searah yang terdiri dari 4 perlakuan dan 5 ulangan. Perlakuan terdiri atas P0 (ransum kontrol), P1 (5\% fermentasi tepung daun Semak Bunga Putih), P2 (10\% fermentasi tepung daun Semak Bunga Putih), dan P3 (15\% fermentasi tepung daun Semak Bunga Putih). Parameter yang diamati adalah konsumsi pakan, pertambahan bobot badan, konversi pakan, dan income over feed cost (IOFC).

Hasil analisa proksimat mendapatkan bahwa, proses fermentasi dapat memperbaiki kualitas kandungan nutrisi tepung daun Semak Bunga Putih. Hasil analisis statistik menunjukkan bahwa, penggunaan fermentasi tepung daun Semak Bunga Putih dalam ransum berpengaruh tidak nyata $(\mathrm{P}>0.05)$ terhadap konsumsi pakan (P0 : 69.12, P1 : 68.25, P2 : 68.68, P3 : 68.07 gram/ekor/minggu), pertambahan bobot badan (P0 : 27.77, P1 : 27.50, P2 : 28.40, P3 : 28.29 gram/ekor/minggu), dan konversi pakan puyuh (P0 : 2.49, P1 : $2.48, \mathrm{P} 2: 2.42$, $\mathrm{P} 3$ : 2.41), tetapi memberikan pengaruh sangat nyata $(\mathrm{P}<0.01)$ terhadap nilai IOFC puyuh $(\mathrm{P} 0: 1105, \mathrm{P} 1$ : 1199, P2 : 1259, P3 : 1344 rupiah).

Kesimpulan dari penelitian ini adalah fermentasi tepung daun Semak Bunga Putih dapat digunakan sebagai substitusi pakan komersial sampai taraf $15 \%$ dalam ransum, karena tidak berpengaruh negatif dan cenderung dapat memperbaiki performa, serta meningkatkan nilai IOFC puyuh pedaging.
\end{abstract}

Kata kunci : Semak Bunga Putih, fermentasi, performa, puyuh.

\section{PENDAHULUAN}

\subsection{Latar Belakang}

Perkembangan usaha peternakan di Indonesia terus mengalami peningkatan dari tahun ke tahun, terlihat dari rata-rata peningkatan produksi komoditas peternakan sebesar $6,52 \%$ dari tahun 2005 sampai dengan 2008 (Direktorat Jenderal Bina Produksi Peternakan, 2009). Pertambahan jumlah penduduk dan meningkatnya kesadaran masyarakat terhadap pemenuhan kebutuhan gizi, mendorong pengembangan dan penganekaragaman ternak sumber protein hewani, terutama pada usaha peternakan unggas.

Puyuh merupakan salah satu ternak unggas yang berpotensi untuk dikembangkan sebagai penghasil daging sumber protein hewani. Puyuh mulai gemar dibudidayakan oleh masyarakat karena memiliki kemampuan untuk menghasilkan daging dan telur yang lebih cepat dibandingkan dengan ternak unggas lainnya, tidak memerlukan modal besar dan perawatan rumit, waktu pemeliharaan cukup singkat, cara pemeliharaan mudah, tidak memerlukan kandang dan lahan luas, serta dagingnya yang dapat diolah menjadi berbagai jenis masakan. Berdasarkan potensi tersebut, perlu dilakukan berbagai usaha untuk meningkatkan keuntungan dalam budidaya puyuh.

Salah satu faktor penting yang mempengaruhi keberhasilan dalam beternak unggas adalah pakan, karena biaya pakan merupakan biaya terbesar dari total biaya produksi, yaitu sekitar 60 sampai 70\% (Rasyaf, 1995). Harga pakan yang semakin mahal merupakan permasalahan yang banyak dihadapi oleh peternak, sehingga banyak dilakukan berbagai macam upaya untuk mengantisipasi permasalahan tersebut, salah satunya adalah dengan memanfaatkan bahan pakan alternatif yang berkualitas, murah, melimpah atau mudah diperoleh, dan tidak mengganggu kesehatan ternak. Potensi bahan pakan alternatif di Indonesia cukup banyak, tetapi kurang atau tidak dapat dimanfaatkan karena beberapa kendala, seperti harus melalui proses pengolahan terlebih dahulu, serta peternak yang tidak mengetahui manfaat dari bahan pakan tersebut.

Semak Bunga Putih (Chromolaena odorata) merupakan salah satu gulma yang mengganggu pertumbuhan tanaman pertanian dan perkebunan. Semak Bunga Putih berpotensi untuk digunakan sebagai bahan pakan alternatif untuk ternak karena mudah diperoleh dan memiliki 
kelebihan berupa kandungan protein yang setara dengan daun lamtoro, turi, dan gamal, serta kandungan asam amino yang baik untuk ternak monogastrik (Marthen, 2007). Pemanfaatan Semak Bunga Putih sebagai bahan pakan alternatif dapat ditingkatkan setelah melakukan proses pengolahan, salah satu diantaranya adalah dengan difermentasi. Fermentasi dilakukan dengan tujuan untuk memperbaiki kualitas kandungan nutrisi Semak Bunga Putih, sehingga jumlah penggunaannya dalam ransum menjadi lebih banyak dan ransum menjadi lebih mudah dicerna oleh puyuh serta menghasilkan lebih banyak nutrisi yang dapat diserap dan digunakan untuk berproduksi.

Berdasarkan permasalahan, keberadaan, serta potensi yang dimiliki Semak Bunga Putih, diharapkan penggunaan fermentasi tepung daun Semak Bunga Putih (Chromolaena odorata) dalam ransum dapat meningkatkan performa dan keuntungan usaha puyuh pedaging.

\section{METODOLOGI PENELITIAN}

\subsection{Tempat dan Waktu}

Pelaksanaan penelitian ini bertempat di kandang Aneka Ternak Politeknik Negeri Jember selama 3 bulan dimulai pada bulan Mei sampai dengan Juli 2012. Analisis proksimat dilakukan di Laboratorium Pakan Ternak, Jurusan Peternakan, Politeknik Negeri Jember.

\subsection{Alat dan Bahan}

Alat dan bahan yaitu Kandang, litter sekam,bambu, kawat ram, lampu dan timbangan analitik (digital). Puyuh umur sehari (Day Old Quail) jantan sebanyak 200 ekor, pakan komersial puyuh starter, bekatul, dan fermentasi tepung daun Semak Bunga Putih (Chromolaena odorata), air minum, vitamin, dan vaksin ND.

\subsection{Metode Penelitian}

Penelitian ini menggunakan rancangan acak lengkap (RAL) pola searah dengan 4 perlakuan dan 5 ulangan.

a) P0 : Ransum control

b) P1 : Ransum menggunakan fermentasi tepung daun Chromolaena odorata $5 \%$

c) P2 : Ransum menggunakan fermentasi tepung daun Chromolaena odorata $10 \%$

d) P3 : Ransum menggunakan fermentasi tepung daun Chromolaena odorata 15\%

\subsection{Parameter Penelitian}

Parameter yang diamati dalam penelitian ini a.Konsumsi pakan (gram/ekor).

b.Pertambahan bobot badan (gram/ekor).

c.Konversi pakan.

d.Income over feed cost (IOFC)(rupiah/ekor).

\section{HASIL DAN PEMBAHASAN \\ 3.1 Kandungan Nutrisi Fermentasi Tepung Daun Semak Bunga Putih}

Hasil analisa proksimat disajikan pada Tabel 2

Tabel 2. Hasil Analisa Proksimat Fermentasi Tepung Daun Semak Bunga Putih

\begin{tabular}{ccccccc}
\hline BAHAN & $\begin{array}{c}\text { BK } \\
\mathbf{\%}\end{array}$ & $\begin{array}{c}\text { PK } \\
\mathbf{\%}\end{array}$ & $\begin{array}{c}\text { LK } \\
\mathbf{\%}\end{array}$ & $\begin{array}{c}\text { SK } \\
\mathbf{\%}\end{array}$ & $\begin{array}{c}\text { Abu } \\
\mathbf{\%}\end{array}$ & $\begin{array}{c}\text { BETN } \\
\mathbf{\%}\end{array}$ \\
\hline $\begin{array}{c}\text { Fermentasi Tepung Daun } \\
\text { Semak Bunga Putih }\end{array}$ & 84.56 & 26.80 & 2.69 & 10.47 & 14.90 & 31.73
\end{tabular}

Sumber : Laboratorium Pakan Ternak Politeknik Negeri Jember (2012)

Hasil analisa proksimat fermentasi tepung daun Semak Bunga Putih pada Tabel 2 mendapatkan bahwa, proses fermentasi dapat memperbaiki kualitas kandungan nutrisi tepung daun Semak Bunga Putih. Hasil analisa proksimat tepung daun Semak Bunga Putih oleh Sagala (2009) mendapatkan kandungan protein kasar $25.51 \%$ dan serat kasar $11.17 \%$, namun setelah dilakukan proses fermentasi dalam penelitian ini mendapatkan kandungan protein kasar sebesar $26.80 \%$, dan kandungan serat kasar sebesar $10.47 \%$.

\subsection{Konsumsi Pakan}

Rataan konsumsi pakan puyuh disajikan pada Tabel 3 
Gilang Nursandhi,A.Marzuki dan Suratno, Substitusi Pakan Komersial Oleh Tepung Daun Semak Bunga Putih (Chromolaena odorata) Terfermentasi Terhadap Performa Dan IOFC (Income Over Feed Cost) Ouyuh Pedaging

Tabel 3. Rataan Konsumsi Pakan Puyuh (gram/ekor/minggu)

\begin{tabular}{cc}
\hline PERLAKUAN & RATAAN \\
\hline P0 & 69.12 \\
P1 & 68.25 \\
P2 & 68.68 \\
P3 & 68.07 \\
\hline
\end{tabular}

Berdasarkan Tabel 3 dapat dikemukakan bahwa, puyuh yang diberi ransum kontrol mengkonsumsi pakan lebih banyak dibandingkan puyuh yang diberi ransum menggunakan fermentasi tepung daun Semak Bunga Putih. Ketiga perlakuan ransum menggunakan fermentasi tepung daun Semak Bunga Putih menunjukkan bahwa, perlakuan 3 menghasilkan rataan konsumsi pakan puyuh paling sedikit dibandingkan perlakuan 1 dan 2 .

Hasil analisis keragaman menunjukkan bahwa, penggunaan fermentasi tepung daun Semak Bunga Putih dalam ransum berpengaruh tidak nyata $(\mathrm{P}>0.05)$ dan tidak memberikan pengaruh negatif terhadap konsumsi pakan puyuh. Ransum yang diberikan pada masing-masing perlakuan memiliki kandungan nutrisi yang tidak berbeda jauh, baik itu kandungan energi, protein kasar, maupun serat kasarnya. Kandungan nutrisi yang sesuai dengan kebutuhan puyuh membuat ransum lebih mudah dicerna, sehingga laju perjalanan makanan di dalam saluran pencernaan Tabel 4. Rataan Pertambahan Bobot Badan Puyuh (gram/ekor/minggu)

\begin{tabular}{cc}
\hline PERLAKUAN & RATAAN \\
\hline P0 & 27.77 \\
P1 & 27.50 \\
P2 & 28.40 \\
P3 & 28.29 \\
\hline
\end{tabular}

Berdasarkan Tabel 4 dapat dikemukakan bahwa, pertambahan bobot badan puyuh yang diberi ransum kontrol lebih kecil dibandingkan puyuh yang diberi ransum menggunakan fermentasi tepung daun Semak Bunga Putih. Ketiga perlakuan ransum menggunakan fermentasi tepung daun Semak Bunga Putih menunjukkan bahwa, perlakuan 2 menghasilkan rataan pertambahan bobot badan puyuh paling besar dibandingkan perlakuan 1 dan 3 .

Hasil analisis keragaman menunjukkan bahwa, penggunaan fermentasi tepung daun Semak Bunga Putih dalam ransum berpengaruh tidak nyata $(\mathrm{P}>0.05)$ dan tidak memberikan pengaruh negatif terhadap pertambahan bobot badan puyuh. Pertambahan bobot badan berbanding lurus dengan konsumsi pakan. Pengaruh dari jumlah konsumsi pakan yang tidak menunjukkan perbedaan yang nyata, berdampak pada asupan nutrisi puyuh yang juga relatif sama. puyuh menjadi lebih cepat, dan nutrisi yang dihasilkan dapat segera diserap untuk pemenuhan kebutuhan. Parakkasi (1990) menyatakan bahwa, faktor yang mempengaruhi konsumsi pakan diantaranya adalah keserasian komposisi gizi dan tingkat kecernaan ransum yang diberikan pada ternak.

Konsumsi pakan puyuh yang tidak berbeda nyata menunjukkan bahwa, tingkat palatabilitas puyuh terhadap fermentasi tepung daun Semak Bunga Putih yang digunakan dalam ransum masing-masing perlakuan cukup baik, sehingga puyuh mengkonsumsi ransum dalam jumlah yang relatif sama. Anggorodi (1995) yang menyatakan bahwa, dalam mengkonsumsi ransum ternak dipengaruhi oleh beberapa faktor seperti, umur, aktifitas ternak, palatabiltas ransum, serta kandungan energi dan protein ransum.

\subsection{Pertambahan Bobot Badan}

Rataan pertambahan bobot badan puyuh disajikan pada Tabel 4
Kartadisastra (1994) menyatakan bahwa, bobot badan puyuh akan ditentukan dari konsumsi pakannya. Semakin besar bobot badan puyuh, semakin banyak jumlah konsumsi pakannya.

Hasil penelitian secara keseluruhan mendapatkan rataan bobot badan awal puyuh sebesar 7.68 gram/ekor, dengan rataan pertambahan bobot badan 27.99 gram/ekor/minggu, dan rataan bobot badan akhir 147.63 gram/ekor, sedangkan Djulardi (2006) menyatakan bobot badan puyuh pada umur 5 minggu adalah 144.36 gram/ekor. Hasil perbandingan menunjukkan bahwa pertambahan bobot badan puyuh dalam penelitian ini cukup baik, karena bobot badan akhir puyuh diatas ratarata bobot badan puyuh pada umumya. Kandungan energi dan protein kasar ransum yang diberikan telah memenuhi standar kebutuhan puyuh.

$$
\text { Proses fermentasi menggunakan }
$$

Aspergillus niger dapat meningkatkan kandungan 
protein dan menurunkan kandungan serat kasar tepung daun Semak Bunga Putih, sehingga ransum perlakuan lebih mudah dicerna oleh puyuh serta menghasilkan lebih banyak nutrisi yang dapat diserap dan digunakan untuk berproduksi, pada akhirnya akan meningkatkan pertambahan bobot badan dan bobot badan akhir puyuh. Wahyu (1997) yang menyatakan bahwa, faktor yang mempengaruhi kecepatan pertumbuhan adalah Tabel 5. Rataan Konversi Pakan Puyuh bangsa, tipe ternak, jenis kelamin, serta energi metabolisme, kandungan protein, dan tingkat kecernaan ransum.

\subsection{Konversi Pakan}

Rataan konversi pakan puyuh dalam penelitian substitusi pakan komersial oleh tepung daun Semak Bunga Putih (Chromolaena odorata) terfermentasi disajikan pada Tabel 5

\begin{tabular}{cc}
\hline PERLAKUAN & RATAAN \\
\hline P0 & 2.49 \\
P1 & 2.48 \\
P2 & 2.42 \\
P3 & 2.41 \\
\hline
\end{tabular}

Berdasarkan Tabel 5 dapat dikemukakan bahwa, nilai konversi pakan puyuh yang diberi ransum kontrol lebih tinggi dibandingkan puyuh yang diberi ransum menggunakan fermentasi tepung daun Semak Bunga Putih. Ketiga perlakuan ransum menggunakan fermentasi tepung daun Semak Bunga Putih menunjukkan bahwa, perlakuan 3 menghasilkan rataan konversi pakan puyuh paling rendah dibandingkan perlakuan 1 dan 2, berarti semakin banyak taraf penggunaan fermentasi tepung daun Semak Bunga Putih dalam ransum, rataan konversi pakannya semakin rendah.

Hasil analisis keragaman menunjukkan bahwa, penggunaan fermentasi tepung daun Semak Bunga Putih dalam ransum berpengaruh tidak nyata $(\mathrm{P}>0.05)$ dan tidak memberikan pengaruh negatif terhadap konversi pakan puyuh. Pengaruh perlakuan dapat meningkatkan nilai efisiensi penggunaan ransum oleh puyuh. Ransum yang menggunakan fermentasi tepung daun Semak Bunga Putih memiliki tingkat kecernaan yang sama dengan ransum kontrol, sehingga jumlah Tabel 6 Rataan IOFC Puyuh (rupiah/ekor) pakan yang dikonsumsi puyuh dapat terkonversi menjadi pertambahan bobot badan yang juga baik. Anggorodi (1995) menyatakan bahwa, nilai kecernaan yang rendah menyebabkan pakan menjadi tidak efisien. Semakin kecil angka konversi maka penggunaan ransum semakin efisien.

Hasil penelitian secara keseluruhan mendapatkan rataan konversi pakan puyuh sebesar 2.45, sedangkan Djulardi (2006) menyatakan konversi pakan puyuh pada umur 5 minggu adalah sebesar 2.66. Hasil perbandingan tersebut menunjukkan bahwa, meskipun perlakuan $0,1,2$, dan 3 memberikan pengaruh tidak berbeda nyata, tetapi konversi pakan puyuh dalam penelitian ini cukup baik, karena nilai konversi pakan yang lebih kecil dari standar nilai konversi pakan puyuh pada umumya.

3.4.Income Over Feed Cost (IOFC). Rataan Income Over Feed Cost (IOFC) disajikan pada Tabel 6

\begin{tabular}{cc}
\hline PERLAKUAN & RATAAN \\
\hline P0 & 1105 \\
P1 & 1199 \\
P2 & 1259 \\
P3 & 1344 \\
\hline
\end{tabular}

Berdasarkan Tabel 6 dapat dikemukakan bahwa, nilai IOFC puyuh yang diberi ransum kontrol lebih kecil dibandingkan puyuh yang diberi ransum menggunakan fermentasi tepung daun Semak Bunga Putih. Ketiga perlakuan ransum menggunakan fermentasi tepung daun Semak Bunga Putih menunjukkan bahwa, perlakuan 3 menghasilkan rataan IOFC puyuh paling besar dibandingkan perlakuan 1 dan 2, berarti semakin banyak taraf penggunaan fermentasi tepung daun Semak Bunga Putih dalam ransum, semakin besar pula rataan IOFC-nya.

Hasil analisis keragaman menunjukkan bahwa, penggunaan fermentasi tepung daun Semak Bunga Putih dalam ransum berpengaruh sangat nyata $(\mathrm{P}<0.01)$ meningkatkan nilai IOFC puyuh. Hal ini ditunjukkan dengan hasil uji beda nyata terkecil yang disajikan pada Tabel 7 
Gilang Nursandhi,A.Marzuki dan Suratno, Substitusi Pakan Komersial Oleh Tepung Daun Semak Bunga Putih (Chromolaena odorata) Terfermentasi Terhadap Performa Dan IOFC (Income Over Feed Cost) Ouyuh Pedaging

Tabel 7 Uji Beda Nyata Terkecil IOFC Puyuh (rupiah/ekor)

\begin{tabular}{cc}
\hline PERLAKUAN & RATAAN \\
\hline 0 & $1105^{\mathrm{a}}$ \\
1 & $1199^{\mathrm{b}}$ \\
2 & $1259^{\mathrm{b}}$ \\
3 & $1344^{\mathrm{c}}$ \\
\hline
\end{tabular}

Keterangan : Notasi yang berbeda menyatakan berbeda nyata pada taraf $1 \%$

Berdasarkan Tabel 7 dapat dikemukakan bahwa, penggunaan fermentasi tepung daun Semak Bunga Putih hingga taraf $10 \%$ dalam ransum memberikan pengaruh yang sama dengan ransum kontrol terhadap nilai IOFC puyuh, tetapi penggunaan pada taraf $15 \%$ sangat nyata dapat meningkatkan nilai IOFC puyuh. Semakin banyak jumlah penggunaan fermentasi tepung daun Semak Bunga Putih dalam ransum, harga ransum semakin murah dan rataan konversi pakannya semakin rendah, sehingga jumlah pakan yang digunakan untuk menghasilkan pertambahan bobot badan semakin sedikit, dan pada akhirnya akan meningkatkan nilai efisiensi biaya pakan. Rasyaf (1995) menyatakan bahwa, semakin efisien ternak mengubah makanan menjadi daging (konversi pakan baik), semakin baik pula nilai IOFC-nya.

\section{KESIMPULAN DAN SARAN}

\subsection{Kesimpulan}

1. Proses fermentasi dapat memperbaiki kualitas kandungan nutrisi tepung daun Semak Bunga Putih (Chromolaena odorata).

2. Penggunaan fermentasi tepung daun Semak Bunga Putih (Chromolaena odorata) sampai taraf $15 \%$ dalam ransum tidak berpengaruh negatif dan cenderung dapat memperbaiki performa puyuh pedaging.

3. Penggunaan fermentasi tepung daun Semak Bunga Putih (Chromolaena odorata) sampai taraf $15 \%$ dalam ransum berpengaruh sangat nyata meningkatkan nilai IOFC puyuh pedaging.

4.2 Saran

Berdasarkan kesimpulan yang diperoleh dari hasil penelitian, menyarankan fermentasi tepung daun Semak Bunga Putih (Chromolaena odorata) dapat digunakan sebagai substitusi pakan komersial dalam ransum puyuh pedaging sampai taraf $15 \%$.

\section{DAFTAR PUSTAKA}

Anggorodi, H. R., 1995. Nutrisi Aneka Ternak Unggas. Gramedia Pustaka Utama, Jakarta.

Bamikole, M. A. dan Osemwenkhoe, A. E., 2004. Converting Bush to Meal : Acase of Chromolaena odorata Feeding to Rabbits. Pakistan Journal of Nutrition, Vol. 3, 4 : 258-261.
Direktorat Jenderal Bina Produksi Peternakan. 2009. Buku Statistik Peternakan. Direktorat Jenderal Bina Produksi Peternakan, Jakarta.

Djulardi, A., 2006. Nutrisi Aneka Ternak dan Satwa Harapan. Andalas University Press, Padang.

Esterlina, Yunilas, dan Handarini, R., 2009. Pemanfaatan Semak Bunga Putih (Chromolaena odorata) sebagai Pakan Terhadap Pertumbuhan Kelinci Jantan. Universitas Sumatera Utara, Medan.

Fardiaz, S., 1989. Analisis Mikrobiologi Pangan. Pusat Antar Universitas Pangan dan Gizi, IPB, Bogor.

Ginting, J., 2009. Pengaruh Semak Bunga Putih (Chromolaena odorata) Dalam Ransum Terhadap Performans Ayam Pedaging Umur DOC - 42 Hari. Universitas Sumatera Utara, Medan.

Hardjo, S., Indrasti, N. S., dan Bantacut, T., 1989. Biokonversi. Pemanfaatan Limbah Industri Pertanian. PAU Pangan dan Gizi IPB, Bogor.

Kartadisastra, H. R., 1994. Pengelolaan Pakan Ayam. Kanisius, Yogyakarta.

Lehninger, A. L., 1991. Dasar-dasar Biokimia. Jilid 2. Erlangga, Jakarta.

Listiyowati, E. dan Roospitasari, K., 2000. Puyuh : Tatalaksana Budidaya Secara Komersial. Penebar Swadaya, Jakarta.

Marthen, L. M., 2007. Pemanfaatan Semak Bunga Putih (Chromolaena odorata) Untuk Peningkatan Produksi Tanaman Dan Ternak. Fakultas Peternakan, Universitas Nusa Cendana Kupang, NTT.

National Research Council. 1994. Nutrient Requirements of Poultry. 9th Revised Edition. National Academy Press, Washington, D.C. 
Jurnal Ilmiah INOVASI, Vol.14 No.2, Hal. 139-144, Mei-September 2014, ISSN 1411-5549

Parakkasi, A., 1990. Ilmu Gizi dan Makanan Ternak Monogastrik. Angkasa, Bandung.

Prawiradiputra, B. R., 2007. Ki Rinyuh (Chromolaena odorata (L) R.M. King dan H. Robinson): Gulma Padang Rumput yang Merugikan. Buletin Ilmu Peternakan Indonesia (WARTAZOA), Vol. 17, No. 1.

Prawirokusumo, S., 1990. Ilmu Gizi Komparatif. BPFE, Yogyakarta.

Rasyaf, M., 1995. Beternak Ayam Pedaging. Penebar Swadaya, Jakarta.

Rovihandono, R., 2005. Memulihkan Rumput Sabana di Sumba Timur Melalui Pemanfaatan Gulma. Yayasan Kehati, Jakarta.

Sagala, N. S., 2009. Pemanfaatan Semak Bunga Putih (Chromolena odorata) Terhadap Pertumbuhan Dan IOFC Dalam Ransum Burung Puyuh (Cortunix-cortunix japonica) Umur 1 Sampai 42 Hari. Universitas Sumatera Utara, Medan.
Saono, S., 1988. Pemanfaatan Jasad Renik dalam Hasil Sampingan atau Sisa-sisa Produk Pertanian. Berita LIPI. Vol. 18, 4 : 1-11.

Sarwono, B. J., 1996. Beternak Ayam Buras. Penebar Swadaya, Jakarta.

Siregar, Z., 2005. Komposisi Zat-zat Nutrisi dalam Pakan Unggas. USU Press, Medan.

Tilman, A. D., Hardi, H., Reksohadiprodjo, S., Prawirokusumo, S., dan Lebdosoekojo, S., 1998. Ilmu Makanan Ternak Dasar. Gadjah Mada University Press, Yogyakarta.

Wahyu, J., 1997. Ilmu Makanan Ternak Unggas. Edisi ke-4. Gajah Mada University Prees, Yogyakarta.

Winarno, F. G. dan Fardiaz, S., 1979. Biofermentasi dan Biosintesis Protein. Angkasa, Bandung. 